\title{
2
}

\section{Energy Metabolism in Neural Tissues in vivo at Rest and in Functionally Altered States}

\section{Louis Sokoloff}

Laboratory of Cerebral Metabolism, National Institute of Mental Health, National Institutes of Health, Bethesda, MD 20892, USA

2.2 Local Cerebral energy Metabolism

2.3 Biochemical Mechanisms of Functional Activation of Energy Metabolism at the Tissue Level

2.4 Localization of Functionally Activated Energy Metabolism at the Tissue Level

2.5 Cellular Localization of Functional Activation of Energy Metabolism

2.5.1 Effects of Increased Extracellular $\mathrm{K}^{+}$and Intracellular $\mathrm{Na}^{+}$Concentrations

2.5.2 Effects of Glutamate on Glucose Utilization in Astroglia

\subsection{INTRODUCTION}

The biochemical pathways of energy metabolism in brain are in most respects like those of other tissues, but special conditions peculiar to the central nervous system produce obstacles to studies of intermediary metabolism of the brain in vivo. For example, the blood-brain barrier restricts the exchange of substrates and products between brain and blood, and, consequently, biochemical reactions normally operating within the brain tissues are often not detectable with traditional in vivo methods based on exchange of substrates and metabolites between the blood and brain. In vitro studies best serve to identify pathways of intermediary

Brain Energetics and Neuronal Activity. Edited by R. G. Shulman and D. L. Rothman (C) 2004 John Wiley \& Sons, Ltd ISBN: 0-470-84720-4 
metabolism, biochemical mechanisms, and potential rather than actual performance, but valid identification of the ultimate substrates and products of cerebral energy metabolism and their rates of utilization and production under conditions of normal brain function can be obtained only in vivo.

The first definitive studies of cerebral energy metabolism in vivo began with the development of the nitrous oxide method by Kety and Schmidt (1948). This method made it possible to determine the rates of cerebral blood flow $(\mathrm{CBF})$ and oxygen consumption $\left(\mathrm{CMRO}_{2}\right)$. Originally designed for use in man it was also applicable in animals, and, furthermore, it could be used in the unanesthetized state, a particularly important requirement to study the normal functioning brain. The method was based on the indirect Fick principle which states that, when a chemically inert tracer (i.e. one that is neither consumed nor produced by a given tissue) is introduced into the circulation, the rate of change in its content in any tissue is equal to the difference between the rates at which it is brought to that tissue in the arterial blood and removed from it in the venous blood. The method originally employed low concentrations of nitrous oxide as the tracer but was subsequently adapted for use with inert radioactive gases, e.g., ${ }^{85} \mathrm{Kr}$, ${ }^{79} \mathrm{Kr}$, and ${ }^{133} \mathrm{Xe}$. Inasmuch as application of the Fick principle requires sampling of both arterial and representative cerebral venous blood for determination of their tracer concentrations, cerebral arteriovenous differences for a variety of substrates and products of cerebral metabolism could also be measured and their rates of utilization or production by the brain calculated as the product of these arteriovenous differences and CBF.

Numerous studies with this method established that cerebral energy metabolism is extraordinarily active in the unanesthetized state (Clarke and Sokoloff, 1999). For example, in normal, conscious, young adult men the brain comprises only about $2 \%$ of total body weight, but it alone consumes about $20 \%$ of the total resting body oxygen consumption. Studies with the method also established that glucose is not only an essential but normally the almost exclusive substrate for the brain's energy metabolism. Under normal conditions the brain utilizes glucose in almost stoichiometric amounts with the oxygen required for the complete oxidation of glucose to $\mathrm{CO}_{2}$ and $\mathrm{H}_{2} \mathrm{O}$ (Table 2.1). For complete stoichiometry $6 \mathrm{~mol}$ of $\mathrm{O}_{2}$ are consumed and $6 \mathrm{~mol}$ of $\mathrm{CO}_{2}$ produced per mole of glucose utilized, i.e., a molar ratio $\left(\mathrm{O}_{2}\right.$ /glucose ratio) of 6.0; the respiratory quotient (R.Q.) (ratio of $\mathrm{CO}_{2}$ production to $\mathrm{O}_{2}$ consumption) is then 1.0. Under normal conditions cerebral glucose utilization $\left(\mathrm{CMR}_{\mathrm{glc}}\right)$ not only accounts for all the $\mathrm{O}_{2}$ consumed, but exceeds the rate for complete stoichiometry with $\mathrm{CMRO}_{2}$ by about $20 \%$, and the measured $\mathrm{O}_{2}$ /glucose ratio is about 5.5 (Table 2.1). In ketotic states, such as those due to starvation, fat-feeding, diabetes, etc., the blood levels of the ketone bodies, D- $\beta$-hydroxybutyrate and acetoacetate, are elevated, and these can substitute partly but not completely for glucose as the substrate for the brain's

Table 2.1. Rates of and relationship between cerebral oxygen consumption and glucose utilization in normal, conscious, young adult men

\begin{tabular}{lc}
\hline Function & Rate \\
\hline $\mathrm{O}_{2}$ consumption $(\mu \mathrm{mol} / 100 \mathrm{~g}$ of tissue $/ \mathrm{min})$ & 156 \\
Glucose utilization $(\mathrm{mmol} / 100 \mathrm{~g}$ of tissue/min) & 31 \\
$\mathrm{O}_{2} /$ glucose ratio $(\mathrm{mol} / \mathrm{mol})$ & 5.5 \\
Glucose equivalent of $\mathrm{O}_{2}$ consumption $(\mu \mathrm{mol} / 100 \mathrm{~g}$ & 26 \\
$\quad$ tissue $/ \mathrm{min})\left(\right.$ assuming $6 \mathrm{~mol} \mathrm{O}_{2}$ per mol of glucose) & \\
Excess of total glucose utilized above glucose oxidized & 5 \\
$\quad$ (mmol/100 g of tissue/min) & \\
$\mathrm{CO}_{2}$ production $(\mu \mathrm{mol} / 100 \mathrm{~g}$ of tissue $/ \mathrm{min})$ & 156 \\
Cerebral respiratory quotient $(\mathrm{R} . \mathrm{Q})$. & 0.97 \\
\hline
\end{tabular}


oxidative metabolism (Owen et al., 1967; Krebs et al., 1971); in such cases the $\mathrm{O}_{2} /$ glucose ratio rises above 6.0.

Numerous studies with the nitrous oxide method and its derivatives demonstrated that cerebral energy metabolism declines in parallel with reduced levels of consciousness. For example, $\mathrm{CMRO}_{2}$ was moderately lower in conditions in which the sensorium was impaired but not to the level of unconsciousness, e.g., diabetic acidosis, moderate hypoglycemia, cerebral arteriosclerosis, etc., and markedly depressed in conditions with complete unconsciousness or coma, e.g., general anesthesia, diabetic coma, insulin coma, hepatic coma, and cerebral ischemia due to increased intracranial pressure caused by brain tumors (Kety, 1950; Clarke and Sokoloff, 1999). All these were, however, pathological conditions in which energy metabolism was probably reduced due to disrupted intracellular biochemical processes, insufficient substrate supply, or lesser demand for energy because of pathologically depressed neuronal functional activity. In physiological and pharmacological states with obviously altered mental functions, not necessarily altered levels of consciousness, such as in schizophrenia, LSD intoxication, mild alcoholic inebriation, sedation, mental exercise during solving of arithmetic problems, etc., no changes in $\mathrm{CMRO}_{2}$ were found. The failure of the nitrous oxide method to detect a relationship between energy metabolic rate and functional activity in the brain was undoubtedly due to the fact that it measured only average rates of oxygen and glucose utilization in the brain as a whole and not in the specific regions of the brain where the functional activities were localized.

\subsection{LOCAL CEREBRAL ENERGY METABOLISM}

The capability to determine local rates of energy metabolism in specific regions of the brain in vivo first became available with development of the $2-\left[{ }^{14} \mathrm{C}\right]$ deoxyglucose $\left(\left[{ }^{14} \mathrm{C}\right] \mathrm{DG}\right)$ method (Sokoloff et al., 1977). This method measures local rates of glucose utilization simultaneously in all regions of the nervous system. Furthermore, it is fully applicable to unanesthetized animals, thus avoiding the complications of alterations of neural functions and metabolism by anesthetic agents. Because of the close to stoichiometric relationship between oxygen and glucose utilization in brain, glucose utilization is generally as good a measure of cerebral energy metabolism as oxygen consumption. 2-[ $\left.{ }^{14} \mathrm{C}\right]$ Deoxyglucose $\left(2-\left[{ }^{14} \mathrm{C}\right] \mathrm{DG}\right)$ was used because it is an analog of glucose with which it competes for blood-brain transport into the brain and for phosphorylation by hexokinase to their hexose-6-phosphate derivatives. Unlike glucose-6-phosphate, however, which is very rapidly metabolized further via the glycolytic and tricarboxylic pathways ultimately to $\mathrm{H}_{2} \mathrm{O}$ and $\mathrm{CO}_{2}, 2-\left[{ }^{14} \mathrm{C}\right] \mathrm{DG}-6$-phosphate can be metabolized to some extent to $2-\left[{ }^{14} \mathrm{C}\right] \mathrm{DG}-1$-phosphate, 2-[ $\left[{ }^{14} \mathrm{C}\right] \mathrm{DG}-1-6$-phosphate, and ${ }^{14} \mathrm{C}$-labeled glycogen, but all the products of $2-\left[{ }^{14} \mathrm{C}\right] \mathrm{DG}$ phosphorylation remain trapped in the cells. Consequently, all the labeled products of $2-\left[{ }^{14} \mathrm{C}\right] \mathrm{DG}$ phosphorylation accumulate with time and are retained within the cells with negligible loss for considerable lengths of time. From a kinetic analysis of the behavior of glucose and tracer concentrations of $2-\left[{ }^{14} \mathrm{C}\right] \mathrm{DG}$ in brain an operational equation was derived with which to compute the local rates of $\mathrm{CMR}_{\mathrm{glc}}$ from the measured times courses of arterial plasma glucose and $2-\left[{ }^{14} \mathrm{C}\right] \mathrm{DG}$ concentrations and the local tissue isotope concentration at the end of the experimental period, usually $30-45 \mathrm{~min}$. Local ${ }^{14} \mathrm{C}$ concentrations in identifiable anatomical structures throughout the brain are determined by the use of quantitative autoradiography (Figure 2.1), a technique originally developed for measurement of local cerebral blood flow in animals with chemically inert, diffusible radioactive tracers (Landau et al., 1955; Freygang and Sokoloff, 1958). The autoradiographs obtained with the 2-[ $\left.{ }^{14} \mathrm{C}\right] \mathrm{DG}$ method can be converted by computerized image-processing techniques into color-coded quantitative images of the brain in which local rates of $\mathrm{CMR}_{\mathrm{glc}}$ are encoded in the color scale. These processed autoradiographic images provide, therefore, the means to visualize local rates of glucose utilization throughout the brain exactly where they occur with a spatial resolution of 100-200 $\mu \mathrm{m}$ (Smith, 1983a). 

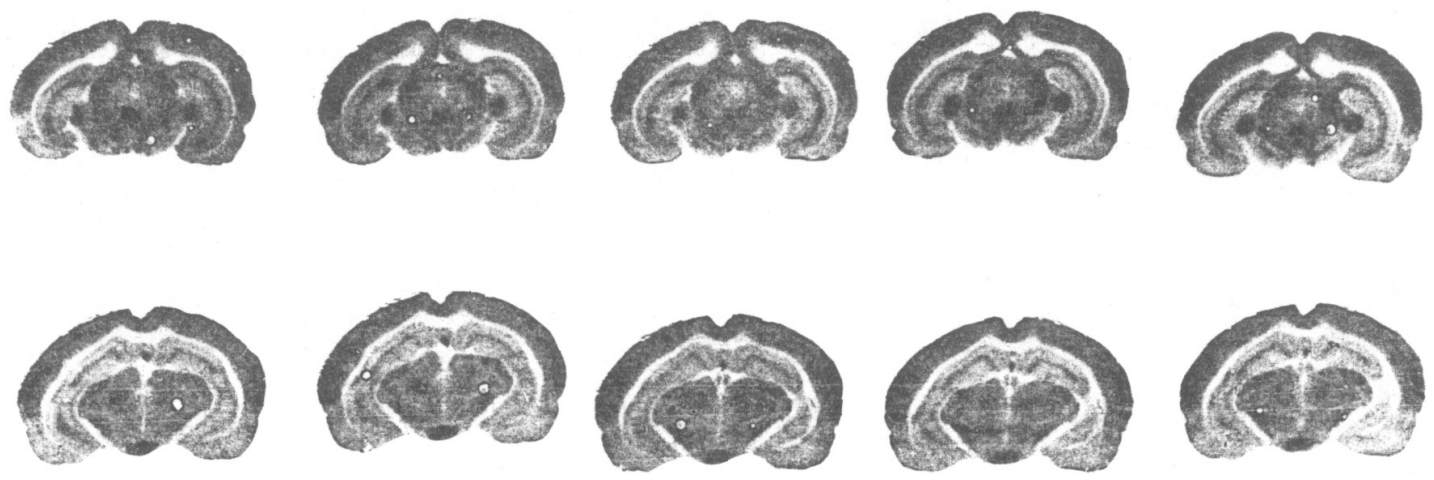

Autoradiographic calibration

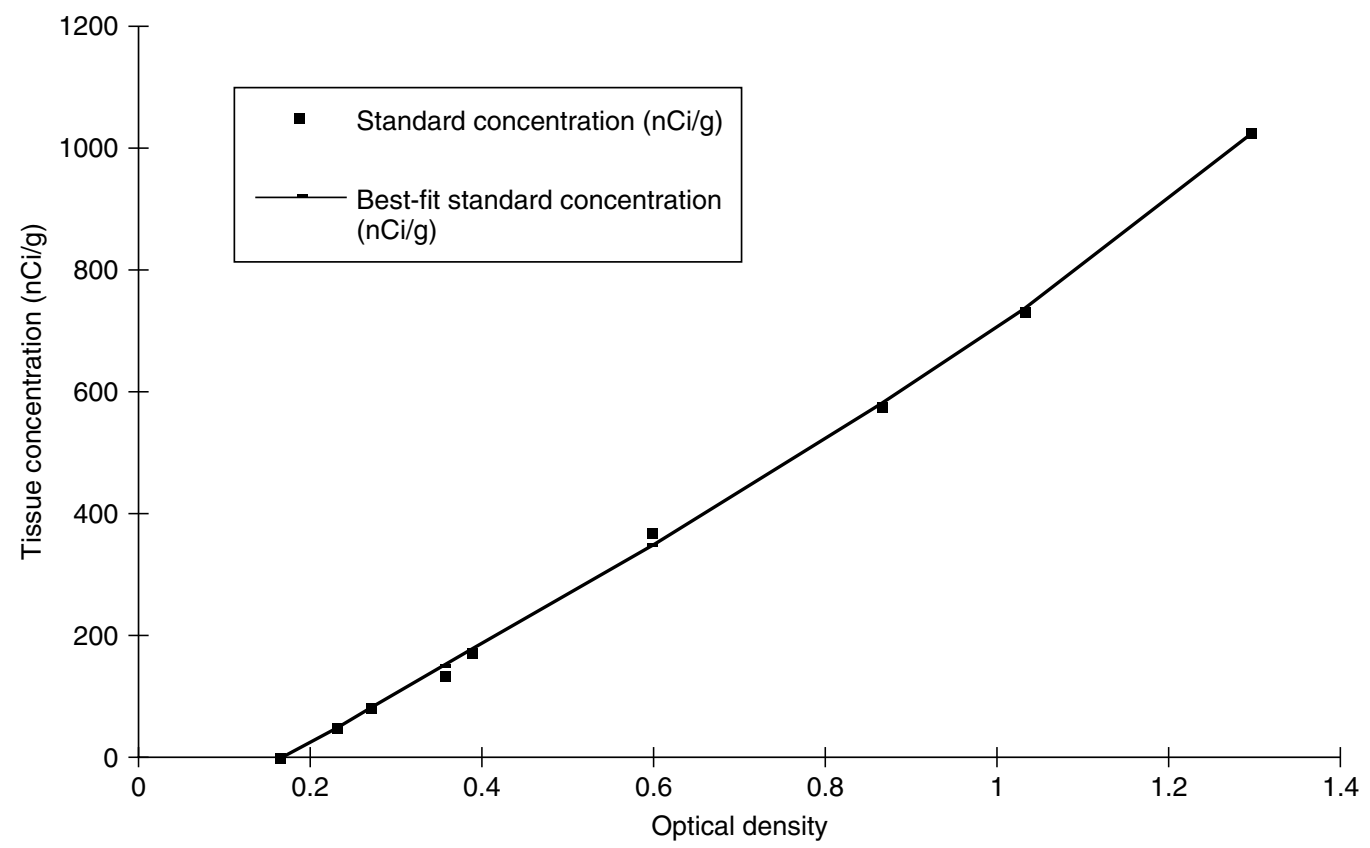

Figure 2.1. $\quad\left[{ }^{14} \mathrm{C}\right] \mathrm{DG}$ autoradiographs of conscious rat brain and of calibrated $\left[{ }^{14} \mathrm{C}\right]$ methylmethacrylate standards as well as the calibration curve between optical density and tissue ${ }^{14} \mathrm{C}$ concentrations derived from densitometry of the standards.

Autoradiography is, of course, not applicable to man. To adapt the $\left[{ }^{14} \mathrm{C}\right] \mathrm{DG}$ method for use in man it was necessary to introduce a $\gamma$-emitting radioactive label into 2-deoxyglucose to allow external detection of the tracer. This was done by attaching ${ }^{18} \mathrm{~F}$ to the carbon in the 2-carbon position of 2-deoxyglucose to produce 2 - $\left[{ }^{18} \mathrm{~F}\right]$ fluoro-2-deoxy-D-glucose $\left({ }^{18} \mathrm{FDG}\right)$, and the local tissue concentrations of label were determined by external scintillation counting with a single photon emission scanner in place of autoradiography (Reivich 
et al., 1979). ${ }^{18} \mathrm{~F}$ is a positron emitter, and the ${ }^{18} \mathrm{FDG}$ method was subsequently adapted further for use with positron emission tomography (PET) (Phelps et al., 1979). PET provides better accuracy and spatial resolution than single photon detection although its spatial resolution in the $\mathrm{mm}$ range is still at least an order of magnitude below the 100-200 $\mu \mathrm{m}$ of the autoradiographic $\left[{ }^{14} \mathrm{C}\right] \mathrm{DG}$ method.

Applications of the $\left[{ }^{14} \mathrm{C}\right] \mathrm{DG}$ and ${ }^{18} \mathrm{FDG}$ methods in both animals and man showed that $\mathrm{CMR}_{\mathrm{glc}}$ varies widely in the various structures of the brain. It is much higher in gray matter than in white matter and is generally reduced by anesthesia (Table 2.2) (Sokoloff et al., 1977). It was also clearly established that neuronal functional activation stimulates energy metabolism in neural tissues just as it does in other tissues (Sokoloff, 1981). The magnitude of the increases in glucose utilization is quantitatively related to the intensity of functional activation. For example, retinal stimulation by randomly timed light flashes raises local $\mathrm{CMR}_{\mathrm{glc}}$ in proportion to the logarithm of the light intensity in those structures of the brain that receive direct projections from the retina (Figure 2.2). (Miyaoka et al., 1979; Sokoloff, 1981). Electrical stimulation of the cervical sympathetic trunk or sciatic nerve increases $\mathrm{CMR}_{\mathrm{glc}}$ linearly with spike frequency in the

Table 2.2. Local rates of cerebral glucose utilization in rats in the conscious state and under light thiopental anesthesia (means \pm SEM)

\begin{tabular}{lccc}
\hline Structure & Conscious (6) & Anesthetized (8) & \% Effect \\
\hline & Gray Matter & & \\
Visual Cortex & $111 \pm 5$ & $64 \pm 3$ & -42 \\
Auditory Cortex & $157 \pm 5$ & $81 \pm 3$ & -48 \\
Parietal Cortex & $107 \pm 3$ & $65 \pm 2$ & -39 \\
Sensory-motor Cortex & $118 \pm 3$ & $67 \pm 2$ & -43 \\
Lateral Geniculate Nucleus & $92 \pm 2$ & $53 \pm 3$ & -42 \\
Medial Geniculate Nucleus & $126 \pm 6$ & $63 \pm 3$ & -50 \\
Thalamus: Lateral Nucleus & $108 \pm 3$ & $58 \pm 2$ & -46 \\
Thalamus: Ventral Nucleus & $98 \pm 3$ & $55 \pm 1$ & -44 \\
Hypothalamus & $63 \pm 3$ & $43 \pm 2$ & -32 \\
Caudate-Putamen & $111 \pm 4$ & $72 \pm 3$ & -35 \\
Hippocampus: Ammon's Horn & $79 \pm 1$ & $56 \pm 1$ & -29 \\
Amygdala & $56 \pm 4$ & $41 \pm 2$ & -27 \\
Cochlear Nucleus & $124 \pm 7$ & $79 \pm 5$ & -36 \\
Nuclei of Lateral Lemniscus & $114 \pm 7$ & $75 \pm 4$ & -34 \\
Inferior Colliculi & $198 \pm 7$ & $131 \pm 8$ & -34 \\
Superior Colliculi & $99 \pm 3$ & $59 \pm 7$ & -40 \\
Superior Olivary Nucleus & $141 \pm 5$ & $104 \pm 7$ & -26 \\
Vestibular Nucleus & $133 \pm 4$ & $81 \pm 4$ & -39 \\
Pontine Gray Matter & $69 \pm 3$ & $46 \pm 3$ & -33 \\
Cerebellar Cortex & $66 \pm 2$ & $44 \pm 2$ & -33 \\
Cerebellar Nuclei & $106 \pm 4$ & $75 \pm 4$ & -29 \\
& & & \\
Corpus Callosum & White Matter & & -29 \\
Genu of Corpus Callosum & $42 \pm 2$ & $30 \pm 2$ & -14 \\
Internal Capsule & $35 \pm 5$ & $30 \pm 2$ & -17 \\
Cerebellar White Matter & $35 \pm 5$ & $29 \pm 2$ & -24 \\
\hline No: The effets of aneshesa & $38 \pm 2$ & $29 \pm 2$ &
\end{tabular}

Note: The effects of anesthesia were statistically significant in every structure $(p<0.05)$.

From Sokoloff et al. (1977). 

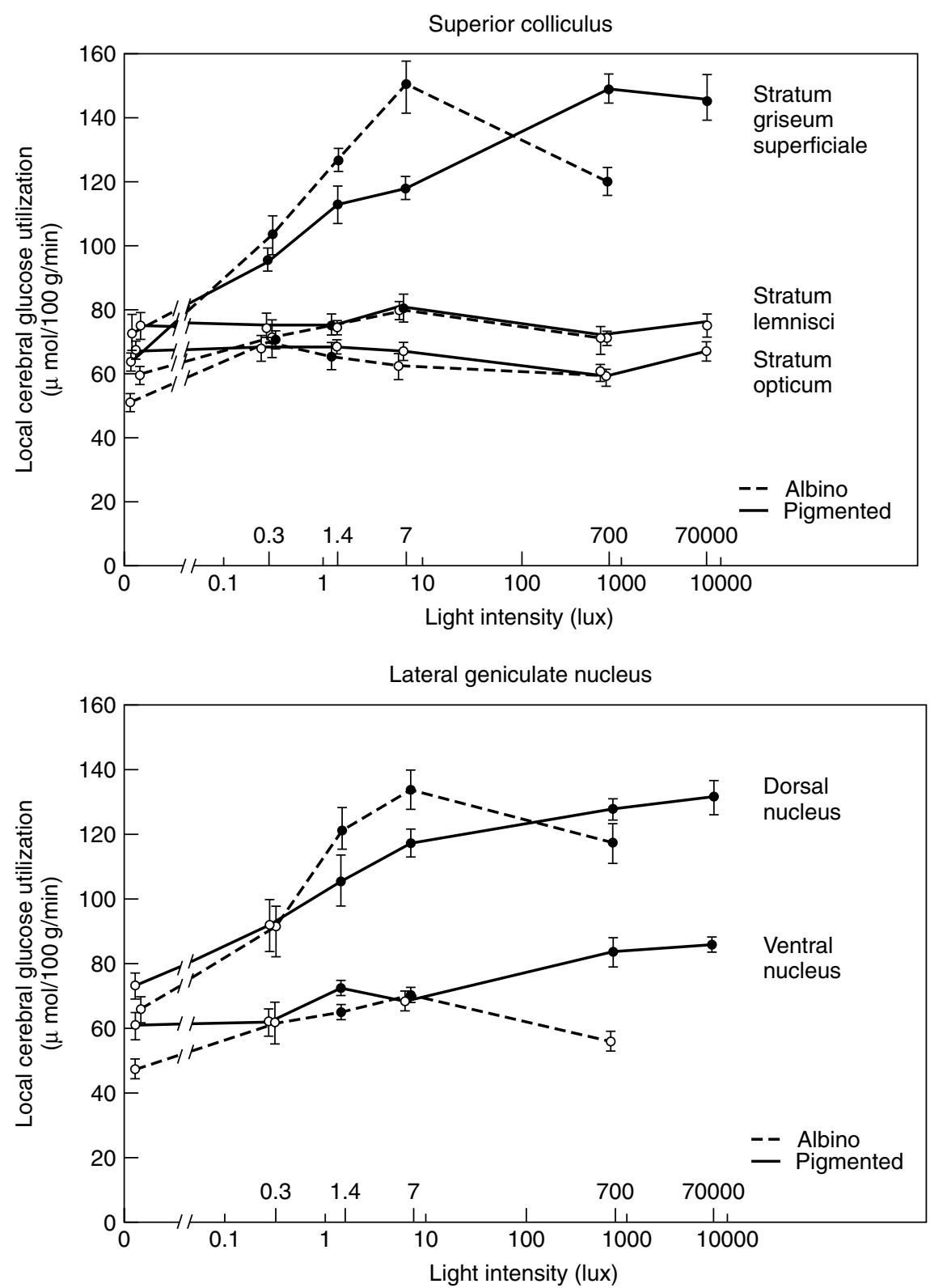

Figure 2.2. Rates of glucose utilization as a function of intensity of retinal illumination with randomly timed light flashes in various layers of superior colliculus and lateral geniculate nucleus of dark adapted albino and pigmented rats. From Miyaoka et al. (1979).

superior cervical ganglion (Yarowsky et al., 1983) and dorsal horn of the lumbar spinal cord, respectively (Figure 2.3) (Kadekaro et al., 1985). The glucose consumed per action potential can be determined from the slope of the straight line and equals $0.4 \mathrm{nmol} / \mathrm{g}$ of tissue per spike in the superior cervical ganglion and $0.6 \mathrm{nmol} / \mathrm{g}$ per spike in the dorsal horn of the lumbar spinal cord (Figure 2.3). 


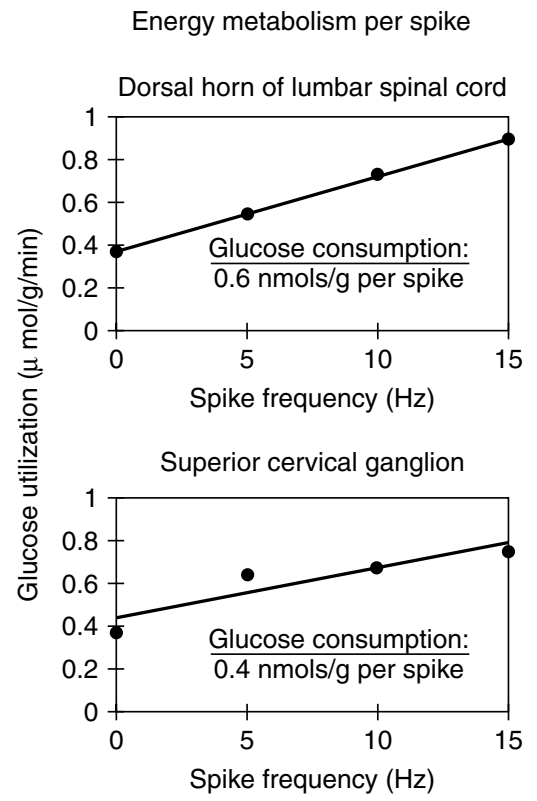

Figure 2.3. Relationship between frequency of action potentials and glucose utilization in dorsal horn of lumbar spinal cord and in superior cervical ganglion during electrical stimulation of sciatic nerve or cervical sympathetic trunk at different frequencies, respectively. Derived from data of Kadekaro et al. (1985) (top) and Yarowsky et al. (1983) (bottom).

\subsection{BIOCHEMICAL MECHANISMS OF FUNCTIONAL ACTIVATION OF ENERGY METABOLISM AT THE TISSUE LEVEL}

Muscles move or support masses against gravitational forces; the heart pumps blood against a pressure head; and kidneys transport water and solutes against concentration and osmotic gradients. These functions involve clearly definable physical work that requires expenditure of energy. It was less obvious what energy-requiring work nervous tissues do when functionally activated. Inasmuch as $\mathrm{CMR}_{\mathrm{glc}}$ increases more or less linearly with spike frequency (Figure 2.3), it was reasonable to presume that the increased energy metabolism was somehow related to the generation, propagation, and conduction of action potentials. Action potentials result from the opening of ion channels that lead to increased $\mathrm{Na}^{+}$influx and $\mathrm{K}^{+}$efflux in neurons; they do not themselves directly consume energy but draw upon the potential energy stored in the membrane potentials. As spike frequencies increase, there are greater ion displacements and larger rises in intracellular $\mathrm{Na}^{+}\left(\left[\mathrm{Na}^{+}\right]_{\mathrm{i}}\right)$ and extracellular $\mathrm{K}^{+}\left(\left[\mathrm{K}^{+}\right]_{\mathrm{o}}\right)$ concentrations and, therefore, the need for more electrogenic $\mathrm{Na}^{+}, \mathrm{K}^{+}$-ATPase activity to restore the ionic gradients across the membranes to their resting levels. This enzyme catalyzes the coupled transport of $\mathrm{Na}^{+}$out of and $\mathrm{K}^{+}$into the cells and consumes one molecule of ATP for every three $\mathrm{Na}^{+}$ion exported and two $\mathrm{K}^{+}$ions imported. Increased ATPase activity lowers intracellular ATP and raises ADP, AMP, phosphate acceptor, and inorganic phosphate concentrations, intracellular changes that stimulate glycolysis and electron transport and, therefore, energy metabolism. Many of the conditions of functional activation in which the $\left[{ }^{14} \mathrm{C}\right] \mathrm{DG}$ method revealed local increases in $\mathrm{CMR}_{\mathrm{glc}}$ have, in fact, been shown to be associated with elevated $\left[\mathrm{K}^{+}\right]_{\mathrm{o}}$ in the activated tissues, and increasing. $\left[\mathrm{K}^{+}\right]_{\mathrm{o}}$ in vivo by applying $\mathrm{K}^{+}$directly to the cerebral cortex, a treatment known to depolarize cell membranes and to cause spreading cortical depression, which itself raises $\left[\mathrm{K}^{+}\right]_{\mathrm{o}}$ even further, profoundly stimulates cerebral cortical glucose utilization (Figure 2.4) (Shinohara et al., 1979). 


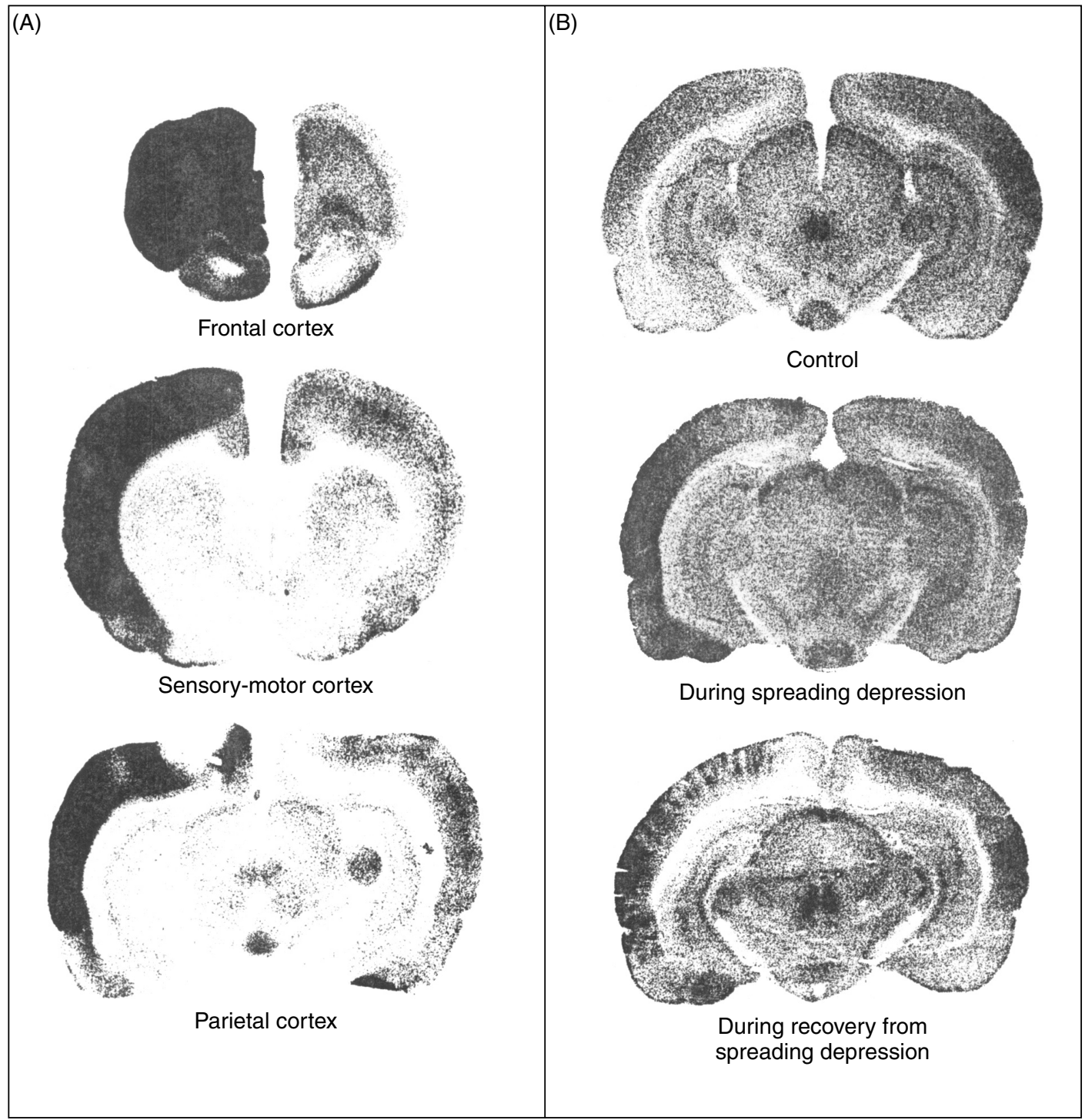

Figure 2.4. $\left[{ }^{14} \mathrm{C}\right]$ Deoxyglucose autoradiographs showing changes in local $\mathrm{CMR}_{\mathrm{glc}}$ during $\mathrm{K}^{+}$-induced spreading cortical depression and during recovery in the rat; greater optical densities indicate higher $\mathrm{CMR}_{\mathrm{glc}}$. In all cases the experimental side on the left was treated with topically applied $\mathrm{KCl}$, and the control side on the right was similarly treated with equivalent concentrations of $\mathrm{NaCl}$. (A) Autoradiographs of brain sections at various levels of cerebral cortex from conscious rat in which spreading cortical depression was produced and sustained on left side by $5 \mathrm{M} \mathrm{KCl}$ applied to surface of intact dura over parietal cortex every 15-20 min; right side treated comparably with $\mathrm{NaCl}$. (B) Autoradiographs of brain sections at level of parietal cortex from three rats under barbiturate anesthesia. Top section is from normal, anesthetized rat; middle section is from similarly anesthetized rat in which $80 \mathrm{mM} \mathrm{KCl}$ in artificial cerebrospinal fluid was repeatedly applied directly to the surface of the left parietal cortex; bottom section is from similarly anesthetized rat studied immediately after return of cortical DC potential to normal after a single wave of spreading depression induced by a single application of $80 \mathrm{mM} \mathrm{KCl}$ to the parieto-occipital cortex of the left side. From Shinohara et al. (1979). 
Table 2.3. Influence of sodium pump activity and neurosecretion on $\left[{ }^{14} \mathrm{C}\right]$ deoxyglucose uptake in posterior pituitary in vitro $^{a}$

\begin{tabular}{|c|c|}
\hline Condition & $\begin{array}{c}{\left[{ }^{14} \mathrm{C}\right] \text { Deoxyglucose uptake }} \\
(\mathrm{Cpm} / 100 \mu \mathrm{g} \text { protein/15 min })\end{array}$ \\
\hline $\begin{array}{l}\text { A. Dependence on activation of sodium pump } \\
\text { Controls (4) } \\
\quad+\text { Electrical stimulation at } 10 \mathrm{~Hz}(4) \\
\quad+\text { Electrical stimulation at } 10 \mathrm{~Hz}+10 \mu \mathrm{M} \text { ouabain (4) }\end{array}$ & $\begin{array}{l}\text { Electrical stimulation } \\
\begin{array}{c}988 \pm 19 \\
1272 \pm 57^{b} \\
1018 \pm 51^{c}\end{array}\end{array}$ \\
\hline $\begin{array}{l}\text { B. Dependence on activation of sodium pump } \\
\text { Controls (14) } \\
+60 \mu \mathrm{M} \text { veratridine }(14) \\
\quad+6 \mu \mathrm{M} \text { tetrodotoxin }(9) \\
+60 \mu \mathrm{M} \text { veratridine }+6 \mu \mathrm{M} \text { tetrodotoxin }(8) \\
+10 \mu \mathrm{M} \text { ouabain }(4) \\
+60 \mu \mathrm{M} \text { veratridine }+10 \mu \mathrm{M} \text { ouabain }(4)\end{array}$ & $\begin{array}{c}\text { Opening } \mathrm{Na}^{+} \text {channels } \\
1381 \pm 50 \\
1891 \pm 85^{b} \\
1209 \pm 84^{c} \\
1551 \pm 72^{c} \\
1318 \pm 57^{c} \\
1218 \pm 120^{c}\end{array}$ \\
\hline $\begin{array}{l}\text { C. Independence from activation of secretion }\left(\mathrm{Ca}^{2+} \text {-free }\right. \\
\text { Controls (in } \mathrm{Ca}^{2+} \text {-free medium) }(6) \\
+60 \mu \mathrm{M} \text { veratridine (in } \mathrm{Ca}^{2+} \text {-free medium) (6) }\end{array}$ & $\begin{array}{c}1142 \pm 38 \\
1681 \pm 78^{b}\end{array}$ \\
\hline
\end{tabular}

\footnotetext{
${ }^{a}$ The values represent means \pm SEM of results obtained in number of experiments indicated in parentheses.

${ }^{b}$ Indicates statistically significant difference from controls $(p<0.001)$.

${ }^{c}$ Indicates no statistical significant difference from controls. From Mata et al. (1980).
}

The possibility that activation of $\mathrm{Na}^{+}, \mathrm{K}^{+}$-ATPase activity by membrane-depolarizing stimulation mediates the coupling of energy metabolism to functional activity was examined directly in studies in which the rat neurohypophysis was electrically stimulated in vitro under conditions known to stimulate its secretion of vasopressin (Mata et al., 1980). Such electrical stimulation raised $\left[{ }^{14} \mathrm{C}\right] \mathrm{DG}$ phosphorylation, indicating increased glucose utilization, and this stimulation was completely blocked by addition of ouabain, a specific inhibitor of $\mathrm{Na}^{+}, \mathrm{K}^{+}$-ATPase (Table 2.3). Addition of veratridine, an agent that depolarizes cell membranes by opening voltage-dependent $\mathrm{Na}^{+}$channels and allows $\mathrm{Na}^{+}$entry into the cells, also markedly stimulated $\left[{ }^{14} \mathrm{C}\right] \mathrm{DG}$ phosphorylation, and this stimulation too was eliminated by ouabain, as well as by tetrodotoxin, a known blocker of voltage-dependent $\mathrm{Na}^{+}$channels (Table 2.3). The stimulation of $\left[{ }^{14} \mathrm{C}\right] \mathrm{DG}$ phosphorylation was not related to increased vasopressin secretion; the neurohypophysis in vitro cannot be stimulated to secrete hormone in $\mathrm{Ca}^{++}$-free medium, but even in such a medium veratridine stimulated $\left[{ }^{14} \mathrm{C}\right] \mathrm{DG}$ phosphorylation (Table 2.3).

It appears then that the extra energy metabolism associated with electrical and functional activation in neural tissue is not used directly in the generation and propagation of action potentials. The energy is used rather to restore ionic gradients and resting membrane potentials that are partially degraded by the action potentials and also to some extent for other processes associated with or secondary to action potentials, such as neurotransmitter release, reuptake, and metabolism, exocytosis, endocytosis, etc.

\subsection{LOCALIZATION OF FUNCTIONALLY ACTIVATED ENERGY METABOLISM AT THE TISSUE LEVEL}

Traditional electrophysiology focuses largely on electrical recordings from neurons, and it was, therefore, originally assumed that the increases in local $\mathrm{CMR}_{\mathrm{glc}}$ associated with functional activation observed with the $\left[{ }^{14} \mathrm{C}\right] \mathrm{DG}$ method were primarily in perikarya. Careful comparisons between the autoradiographs produced by the $\left[{ }^{14} \mathrm{C}\right] \mathrm{DG}$ method and the stained brain sections from which they were prepared did not, however, 


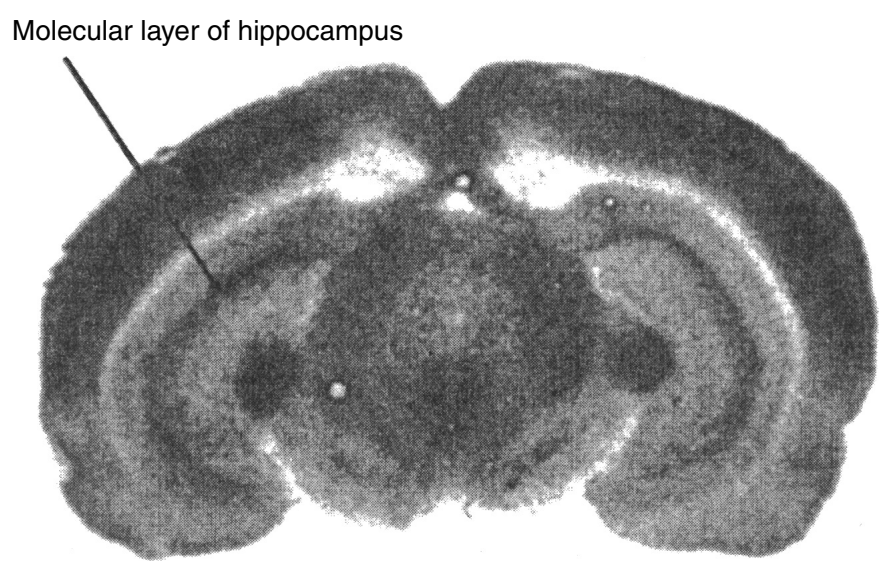

Figure 2.5. $\quad\left[{ }^{14} \mathrm{C}\right]$ Deoxyglucose autoradiograph of normal, conscious rat brain. Greater optical density reflects greater $\mathrm{CMR}_{\mathrm{glc}}$. Note high rate in molecular layer of hippocampus.

support this assumption. In the autoradiographs higher rates of glucose utilization are reflected in increasing darkness in the films (Figure 2.1). It was noted in the autoradiographs that the most metabolically active region in the hippocampus, which was at first thought to represent the cell-rich pyramidal cell layer, was actually the molecular layer, a region predominantly rich in synapses and poor in cell bodies (Figure 2.5).

In the striate cortex of the normal monkey $\mathrm{CMR}_{\mathrm{glc}}$ is highest in a sub-layer of Layer IV that is not particularly rich in cellular elements; it is the layer where axonal terminals of the afferent geniculocalcarine pathway synapse with dendrites of neurons situated in other laminae of the visual cortex (Figure 2.6A, C) (Kennedy et al., 1976). It is in this neuropil-rich layer that $\mathrm{CMR}_{\mathrm{glc}}$ is most reduced when visual input is interrupted (Figure 2.6B).

The hypothalamo-neurohypophysial pathway originates in cell bodies in the supraoptic and paraventricular nuclei in the hypothalamus and terminates in the neurohypophysis, $40 \%$ of which consists of axonal terminals of the afferent tract (Nordmann, 1977). Osmotic stimulation by salt-loading is known to activate this pathway to stimulate vasopressin release from the neurohypophysis. Salt-loading was found also to stimulate local $\mathrm{CMR}_{\mathrm{glc}}$ markedly in the neurohypophysis but to have no apparent effect on $\mathrm{CMR}_{\mathrm{glc}}$ in the supraoptic and paraventricular nuclei (Figure 2.7) (Schwartz et al., 1979). In contrast, hypotension produced by $\alpha$-adrenergic blockade with phenoxybenzamine or hemorrhage was found to stimulate local $\mathrm{CMR}_{\mathrm{glc}}$ markedly in both these nuclei (Figure 2.7). The difference is that osmotic stimulation acts directly on the cell bodies to activate the hypothalamo-neurohypophysial pathway whereas hypotension exerts its effects on the cell bodies in these nuclei indirectly via afferent inputs from the nucleus tractus solitarius in the brain stem that are part of the neural pathways of the baroreceptor reflexes. Results such as these suggested that it is mainly the energy metabolism in regions rich in neuropil and synapses and not cell bodies that is linked to functional activity.

To compare directly the effects of functional activation on local $\mathrm{CMR}_{\mathrm{glc}}$ in perikarya and nerve terminals simultaneously in the same pathway, Kadekaro et al. (1985) stimulated the sciatic nerve at different frequencies and examined the effects on $\mathrm{CMR}_{\mathrm{glc}}$ in both the dorsal root ganglia and the dorsal horn of corresponding segments of the lumbar spinal cord. The advantage of this system is that the body of the dorsal root ganglion contains perikarya devoid of neural processes, thus allowing examination of cell bodies free of nerve terminals simultaneously with the nerve terminals of the same pathway in the dorsal horn of the spinal cord. The results confirmed that it is $\mathrm{CMR}_{\mathrm{glc}}$ in the region of the nerve terminals and not in the cell bodies that is linked to the functional activity. Glucose utilization increased linearly with the 
(A)
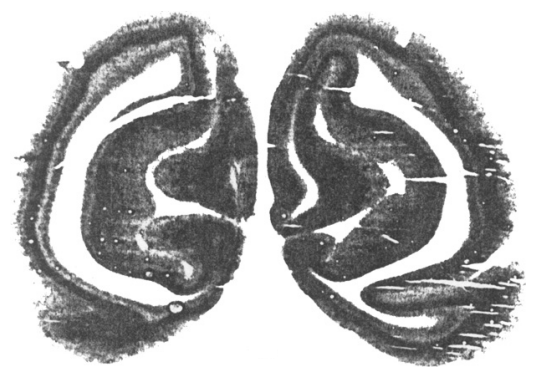

(B)
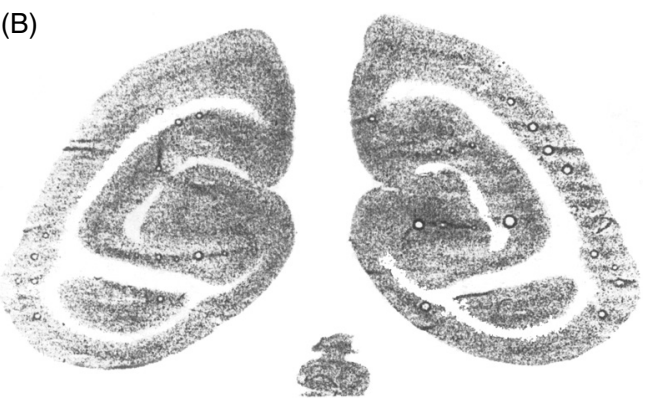

(C)

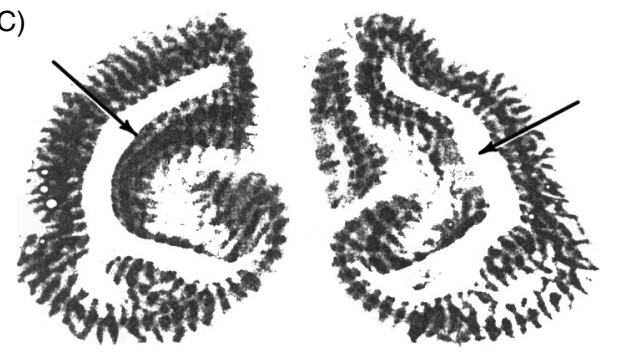

Figure 2.6. $\quad\left[{ }^{14} \mathrm{C}\right]$ Deoxyglucose autoradiographs demonstrating effects of bilateral and monocular visual occlusion on local $\mathrm{CMR}_{\mathrm{glc}}$ in striate cortex of conscious monkey. Greater optical density indicates greater $\mathrm{CMR}_{\mathrm{glc}}$. (A) Striate cortex from animal with both eyes open. Note heterogeneity in laminae; the darkest lamina corresponds to Layer IV. (B) Striate cortex from monkey with both eyes patched. Note general reduction in density and almost complete disappearance of laminar heterogeneity, especially in Layer IV. (C) Striate cortex from animal with only right eye patched. Left half of autoradiograph corresponds to left hemisphere contralateral to occluded eye. Note alternating dark and light columns traversing the full thickness of the striate cortex which represent the ocular dominance columns. The dark bands represent the columns for the open eye; the light bands represent the columns for the patched eye and demonstrate the reduced glucose utilization resulting from reduced visual input. The arrows point to regions of bilateral asymmetry; these are the loci of representation of the blind spots of the visual fields. From Kennedy et al. (1976).

increasing frequency of stimulation of the sciatic nerve in the dorsal horn of the lumbar spinal cord, but it did not budge from its baseline levels in the cell bodies of the same pathway in the dorsal root ganglia (Figure 2.8). The lack of a metabolic response to electrical stimulation in the perikarya in the dorsal root ganglion may be surprising, but there is evidence that the soma membrane of neurons is not very excitable and not very productive of action potentials because of a relative paucity of voltage-gated $\mathrm{Na}^{+}$channels. Smith (1983b), using patch clamp electrodes, obtained evidence that soma and dendrites of spinal cord neurons and soma of dorsal root ganglion cells cultured in vitro do not generate action potentials. Freygang 


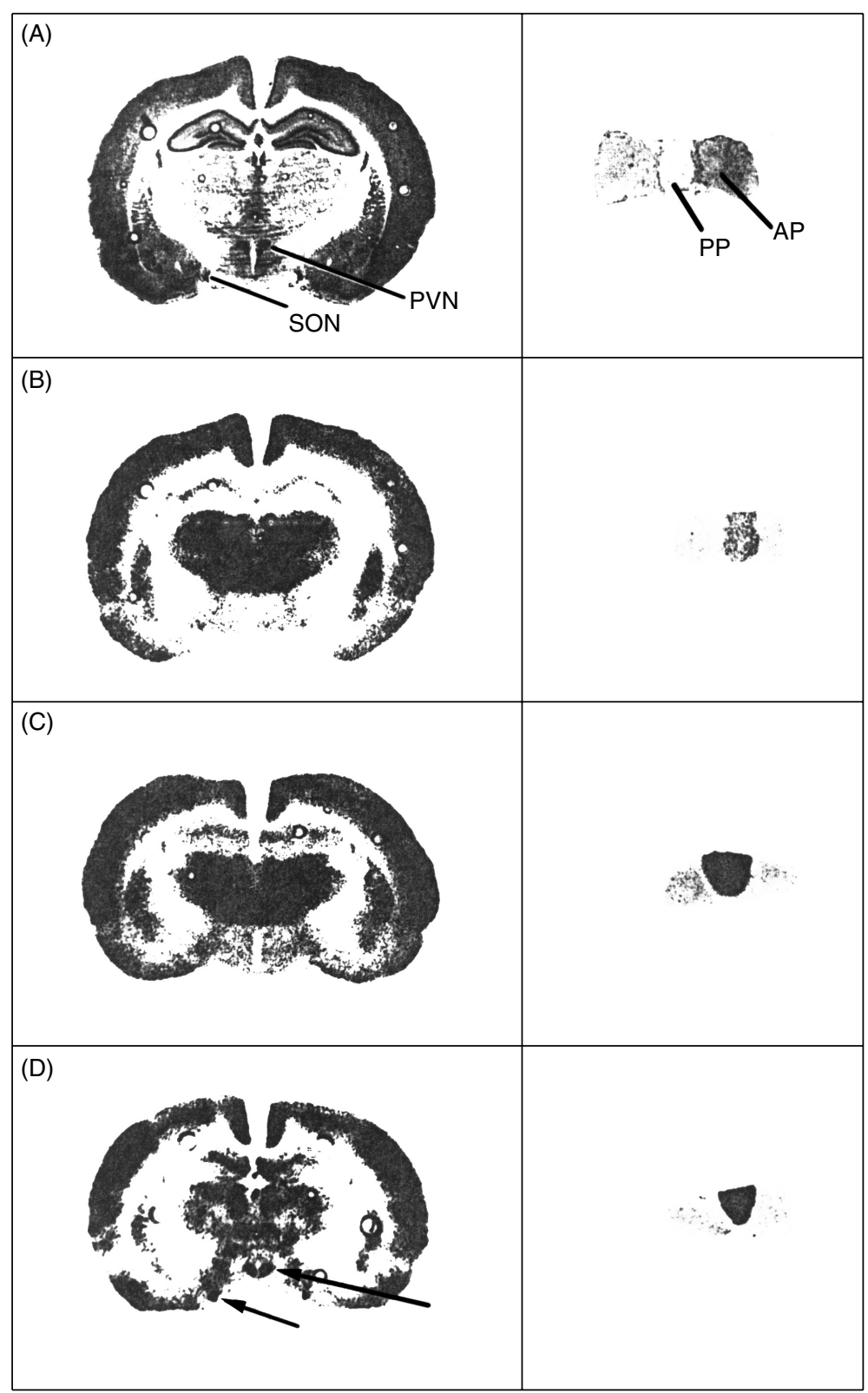

Figure 2.7. Effects of activation of hypothalamo-neurohypophysial pathway by salt-loading or hypotension on local cerebral glucose utilization in the conscious rat. (A) Histological sections of brain stained with cresyl violet (Nissl) and pituitary stained with toluidine blue demonstrating positions of supraoptic nucleus (SON), paraventricular nucleus (PVN), posterior pituitary (PP), and anterior pituitary (AP). (B) $\left[{ }^{14} \mathrm{C}\right]$ Deoxyglucose autoradiographs of brain and pituitary from normal control rat drinking only water. (C) $\left[{ }^{14} \mathrm{C}\right]$ Deoxyglucose autoradiographs from rat given $2 \%$ (w/v) $\mathrm{NaCl}$ in drinking water for 5 days. Note selective marked increase in density in posterior hypophysis, indicating increased glucose utilization. (D) $\left[{ }^{14} \mathrm{C}\right]$ Deoxyglucose autoradiographs from rat made hypotensive by administration of $20 \mathrm{mg} / \mathrm{kg}$ of phenoxybenzamine $45-60 \mathrm{~min}$ prior to administration of the $\left[{ }^{14} \mathrm{C}\right]$ deoxyglucose. Note selective increases in labeling of supraoptic and paraventricular nuclei and posterior pituitary. From Schwartz et al. (1979). 


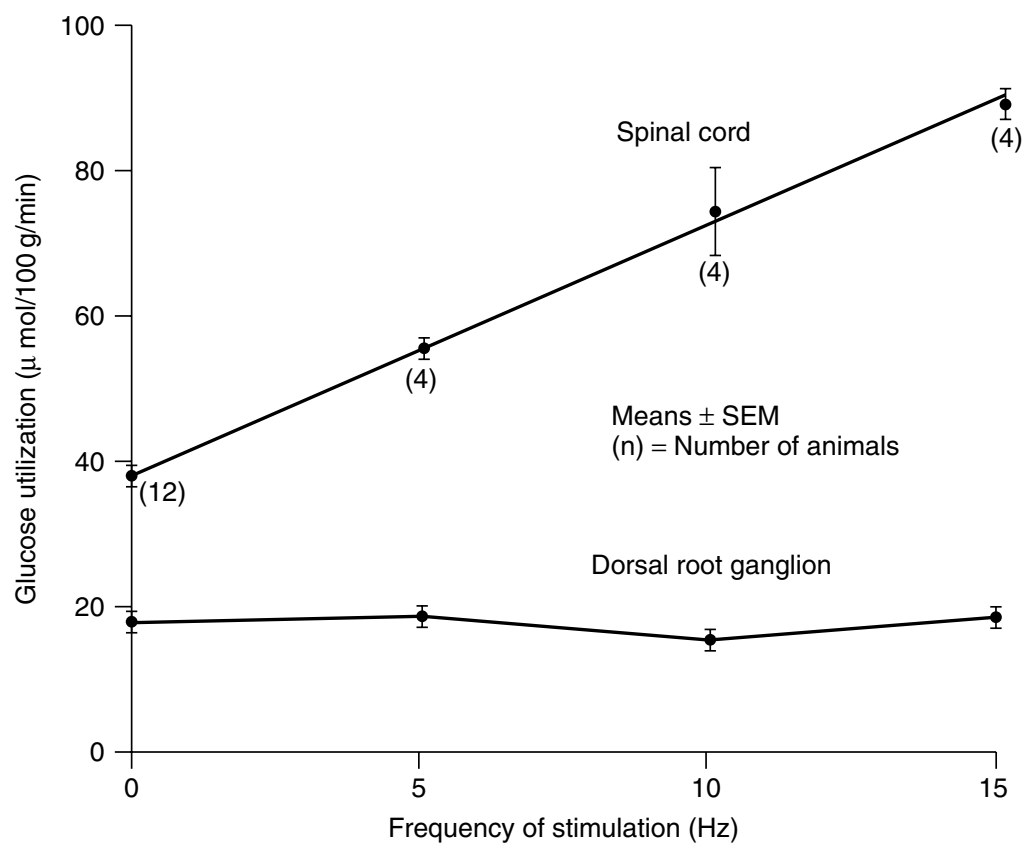

Figure 2.8. Frequency-dependent effects of electrical stimulation of sciatic nerve on local $\mathrm{CMR}_{\mathrm{glc}}$ in dorsal root ganglion and dorsal horn of lumbar spinal cord. Error bars represent SEM. From Kadekaro et al. (1985).

(1958) and Freygang and Frank (1959) had previously concluded from analyses of extracellular potentials recorded from single spinal motor neurons and single neurons in the lateral geniculate nucleus that the soma-dendritic membrane can be driven synaptically to produce post-synaptic potentials but not propagating action potentials. Conduction through the cell body is mainly by electrotonic conduction rather than by action potentials. If action potentials do indeed mediate the coupling of energy metabolism to functional activity but are absent in the perikarya, then increased glucose metabolism due to functional activation is not to be expected in the perikarya. Some energy metabolism does, of course, proceed in cell bodies even at rest, but it is probably used more for vegetative, biosynthetic, and transport processes needed to maintain cellular structural and functional integrity rather than for processes directly related to functional activity. Some energy-consuming processes within the cell bodies that are related to intracellular signal transduction must also be activated by functional activation, but apparently their requirements are too small to be detected in the overall energy consumption of the cell.

The finding that rates of energy metabolism are linked to spike frequency in the terminal zones of the afferent pathways in the neuropil and not in cell bodies in the pathway should help to resolve questions about metabolic responses associated with functional excitation and inhibition. Glucose utilization has sometimes been observed to increase in structures in which electrophysiological evidence indicated inhibition of neuronal activity, thus raising questions whether active inhibition required energy just like excitation. It appears, however, that it is the spike activity in the afferent nerve terminals that correlates with the energy consumption, and this activity is the same whether the terminals are releasing excitatory or inhibitory neurotransmitters. The energy metabolism of the post-synaptic cell bodies, whether activated or inhibited, is not significantly altered, and to determine which has occurred, it is necessary to look downstream at the next synapses in the projection zones of those neurons. Glucose utilization is depressed in the projection zones of inhibited neurons and increased in the projection zones of excited neurons. 


\subsection{CELLULAR LOCALIZATION OF FUNCTIONAL ACTIVATION OF ENERGY METABOLISM}

The neuropil, in which functionally activated energy metabolism is localized, contains not only neuronal elements, e.g., axonal terminals, dendritic processes, and synapses, but astrocytic processes as well. Because stimulation of local $\mathrm{CMR}_{\mathrm{glc}}$ is linked to $\mathrm{Na}^{+}, \mathrm{K}^{+}$-ATPase activity and the frequency of action potentials which are associated with increased $\mathrm{Na}^{+}$influx and $\mathrm{K}^{+}$efflux, some of the increased energy metabolism must be used to restore the ionic gradients in the neuronal elements where the action potentials are produced. Astrocytic processes envelop the synapses and could also be involved in the metabolic response. Astrocytes are believed to regulate $\left[\mathrm{K}^{+}\right]_{\mathrm{o}}$ either by passive diffusion (Orkand et al., 1966; Medzihradsky et al., 1971) and/or active transport (Henn et al., 1972) following increases in $\left[\mathrm{K}^{+}\right]_{\mathrm{o}}$ resulting from neuronal excitation (Hertz, 1977; Erecinska and Silver, 1994), and studies with tissue slices (Yarowsky et al., 1986; Badar-Goffer et al., 1992) or cultured cells (Cummins et al., 1979a; Cummins et al., 1979b; Brookes and Yarowsky, 1985; Hertz and Peng, 1992; Peng et al., 1994) have indicated that energy is consumed in the process. The spatial resolution of the autoradiographic $\left[{ }^{14} \mathrm{C}\right] \mathrm{DG}$ method is limited to $100-200 \mu \mathrm{m}$ (Smith, 1983a) which is inadequate to identify the specific cellular or subcellular elements in neuropil that contribute to the increases in $\mathrm{CMR}_{\mathrm{glc}}$ during functional activation.

\subsubsection{Effects of Increased Extracellular $\mathrm{K}^{+}$and Intracellular $\mathrm{Na}^{+}$Concentrations}

To approach this question, studies have been carried out in vitro with cells in culture. Changes in the extracellular medium expected to result from increased spike activity in vivo were simulated in vitro, and their effects on glucose metabolism of cultured neurons and astroglia examined. Spike activity in axonal terminals leads to increased extracellular $\mathrm{K}^{+}$and intracellular $\mathrm{Na}^{+}$concentrations and release of neurotransmitters. Therefore, the effects of elevated $\left[\mathrm{K}^{+}\right]_{\mathrm{o}},\left[\mathrm{Na}^{+}\right]_{\mathrm{i}}$, and the extracellular concentration of glutamate, the most prevalent excitatory neurotransmitter in brain, on $\left[{ }^{14} \mathrm{C}\right] \mathrm{DG}$ phosphorylation to $\left[{ }^{14} \mathrm{C}\right] \mathrm{DG}-$ 6-phosphate, a measure of glucose utilization, were examined in cultured neurons and astroglia (Takahashi et al., 1995).

Increasing $\left[\mathrm{K}^{+}\right]_{\mathrm{o}}$ in the range of $5.4-56 \mathrm{mM}$ stimulated $\left[{ }^{14} \mathrm{C}\right] \mathrm{DG}$ phosphorylation in both neuronal and mixed neuronal-astroglial cultures (Figure 2.9) (Takahashi et al., 1995), and these increases were prevented by ouabain, implicating $\mathrm{Na}^{+}, \mathrm{K}^{+}$-ATPase in the mechanism of the effect. Raising $\left[\mathrm{K}^{+}\right]_{\mathrm{o}}$ in the same range had no such effect in the cultured astroglia. In fact, the highest levels of $\left[\mathrm{K}^{+}\right]_{\mathrm{o}}$ examined tended to inhibit $\left[{ }^{14} \mathrm{C}\right] \mathrm{DG}$ phosphorylation in astroglia (Figure 2.9). On the other hand, promoting $\mathrm{Na}^{+}$entry into the cells and increasing $\left[\mathrm{Na}^{+}\right]_{\mathrm{i}}$ either by opening membrane voltage-gated $\mathrm{Na}^{+}$channels with veratridine or by adding the $\mathrm{Na}^{+}$ionophore monensin markedly stimulated $\left[{ }^{14} \mathrm{C}\right] \mathrm{DG}$ phosphorylation in astroglia, but only if $\mathrm{Na}^{+}$were present in the extracellular medium (Figure 2.10) (Brookes and Yarowsky, 1985; Takahashi et al., 1995). Tetrodotoxin, which blocks voltage-dependent $\mathrm{Na}^{+}$channels, did not alter baseline rates of $\left[{ }^{14} \mathrm{C}\right] \mathrm{DG}$ phosphorylation in astroglia, and, as expected, prevented the stimulation by veratridine and had no effect on the stimulation by monensin (Figure 2.10). Inhibiting $\mathrm{Na}^{+}, \mathrm{K}^{+}$-ATPase activity with ouabain lowered the basal rate of $\left[{ }^{14} \mathrm{C}\right] \mathrm{DG}$ phosphorylation, completely blocked the stimulation by veratridine, and partially suppressed the stimulation by monensin (Figure 2.10). The absence of a tetrodotoxin effect on the monensin stimulation can be explained by the fact that monensin-induced $\mathrm{Na}^{+}$entry is not through voltage-dependent $\mathrm{Na}^{+}$channels and is, therefore, insensitive to blockade by tetrodotoxin. The less than complete blockade of the monensin stimulation by ouabain can also be explained by the fact that monensin is a $\mathrm{Na}^{+} / \mathrm{H}^{+}$exchanger that exchanges extracellular $\mathrm{Na}^{+}$for intracellular $\mathrm{H}^{+}$. It, therefore, raises $\mathrm{Na}^{+}$ and lowers $\mathrm{H}^{+}$concentrations in the cells, both ionic changes that can enhance glucose metabolism, the 


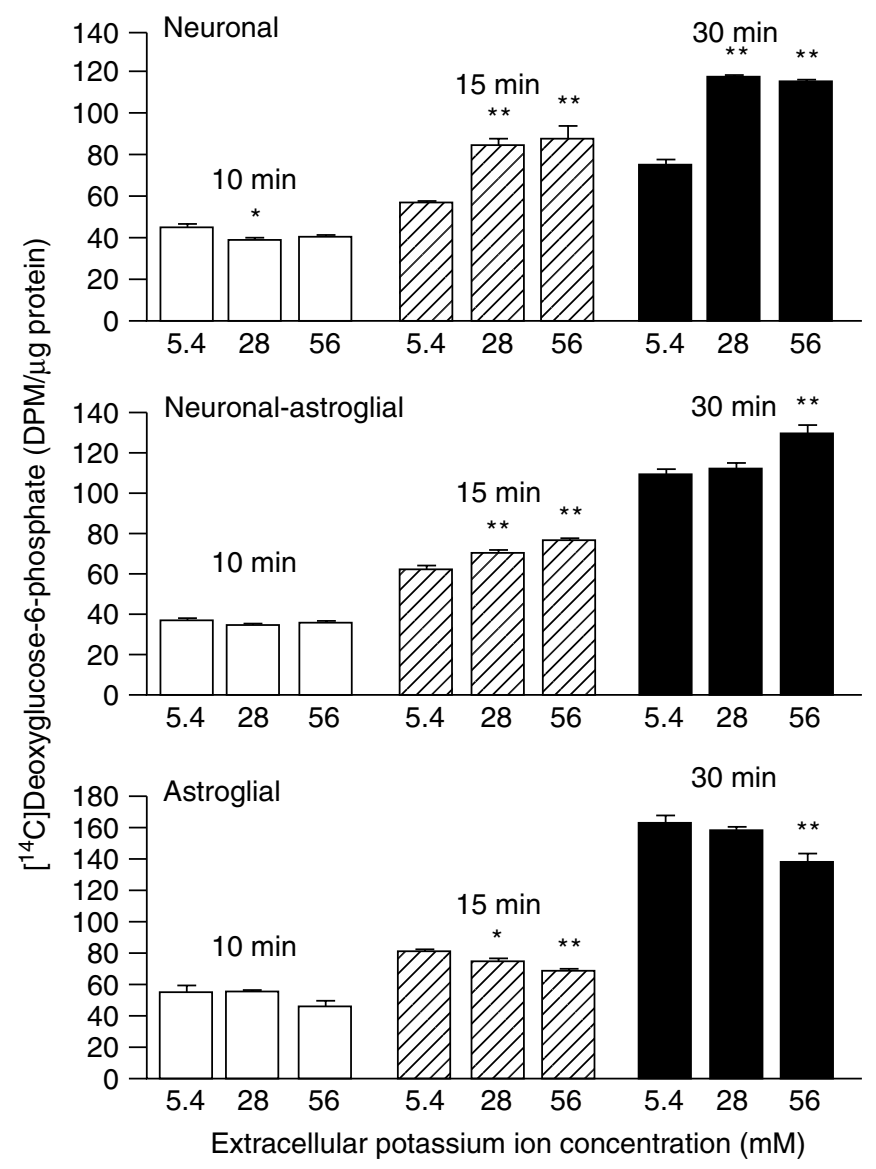

Figure 2.9. Effects of $\left[\mathrm{K}^{+}\right]_{\mathrm{o}}$ on rates of $\left[{ }^{14} \mathrm{C}\right] \mathrm{DG}$ phosphorylation in cultured neurons, mixed neuronal-astroglia cultures, and astroglia cultures. Values are means \pm SEM obtained from quadruplicate wells. Numbers above bars indicate duration of incubation. ${ }^{*} p<0.05,{ }^{* *} p<0.01$ compared to the $5.4 \mathrm{mM}\left[\mathrm{K}^{+}\right]_{\mathrm{o}}$ (Dunnett's test for multiple comparisons). Representative of at least three such experiments for each condition. From Takahashi et al. (1995).

former by ouabain-sensitive stimulation of $\mathrm{Na}^{+}, \mathrm{K}^{+}$-ATPase activity, and the latter by ouabain-insensitive stimulation of phosphofructokinase activity due to increased intracellular $\mathrm{pH}$.

\subsubsection{Effects of Glutamate on Glucose Utilization in Astroglia}

Glutamate, the most prevalent excitatory neurotransmitter in the brain, is toxic to neurons, and must, therefore, be rapidly cleared from the extracellular space when it is released at glutamatergic synapses. Astrocytes, which have processes that envelop the synapses, carry out this function. They take up the glutamate from the extracellular space and convert it to glutamine, both steps that involve the consumption of energy. Addition of glutamate to the medium stimulates glucose utilization by astroglial cultures (Pellerin and Magistretti, 1994; Takahashi et al., 1995). This stimulation is $\mathrm{Na}^{+}$dependent, ouabain sensitive, unaffected by tetrodotoxin, and insensitive to NMDA and non-NMDA glutamate receptor antagonists (Figure 2.11). DL-Threo- $\beta$-hydroxyaspartate, which competes with glutamate for uptake by 

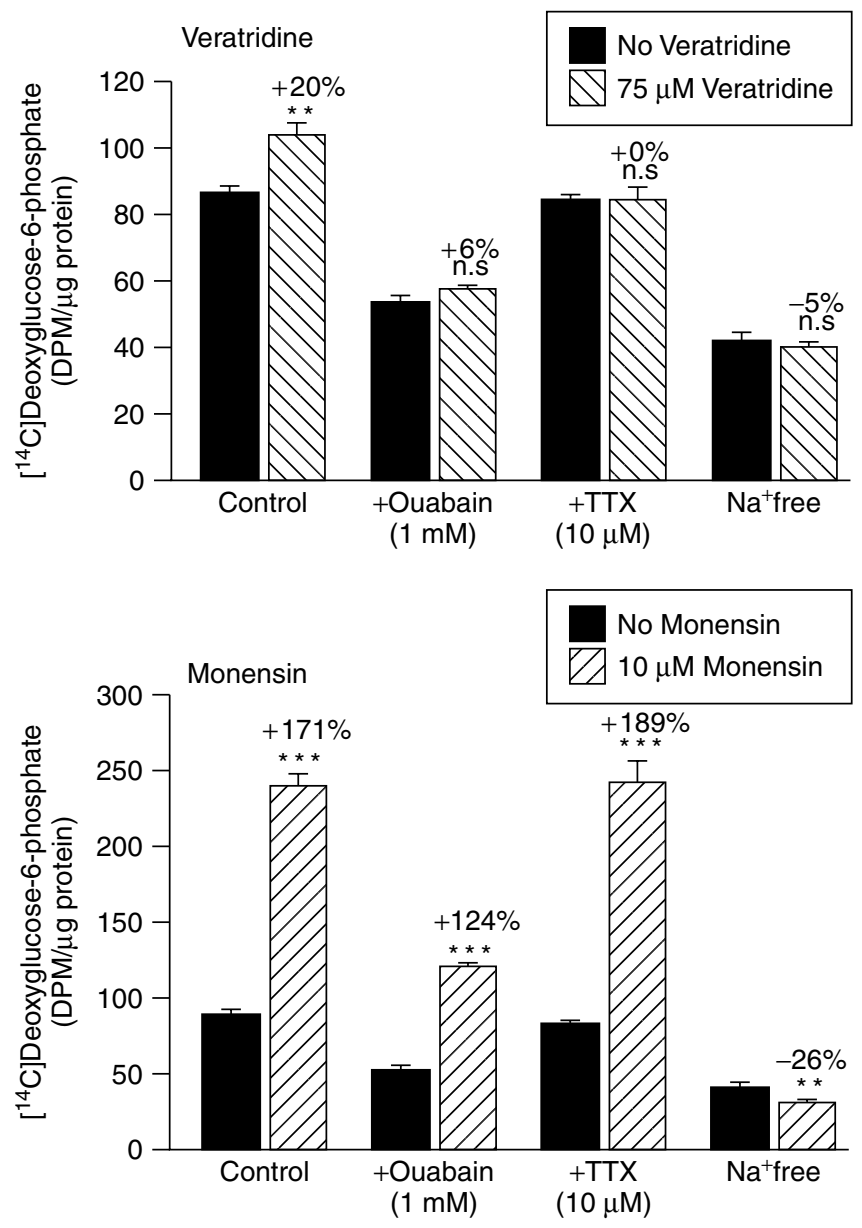

Figure 2.10. Effects of veratridine (upper) and monensin (lower) on $\left[{ }^{14} \mathrm{C}\right] \mathrm{DG}$ phosphorylation in astroglia (21-day old culture, no dbcAMP) and the effects of ouabain, tetrodotoxin (TTX), and $\mathrm{Na}^{+}$-free medium on the veratridine and monensin effects. Values are means \pm SEM obtained from measurements of quadruplicate wells in three experiments. Numbers above bars indicate percent difference from each control. Representative of in three different astroglial preparations. ${ }^{* *} p<0.01 ;{ }^{* *} p<0.001$; n.s., not statistically significant from each control (grouped $t$ test). From Takahashi et al. (1995).

the $\mathrm{Na}^{+}$/glutamate co-transport system (Flott and Seifert, 1991), itself stimulates glucose utilization, and glutamate no longer stimulates in its presence. The hydroxyaspartate stimulation is also blocked by ouabain, absent in $\mathrm{Na}^{+}$-free medium, and unaffected by tetrodotoxin and inhibitors of NMDA or non-NMDA receptors. These results show that the glutamate stimulation of glucose utilization by astroglia does not involve NMDA and non-NMDA glutamate receptors or voltage-dependent $\mathrm{Na}^{+}$channels in the astroglia. It is due instead to the activation of $\mathrm{Na}^{+}, \mathrm{K}^{+}$-ATPase activity by the increase in $\left[\mathrm{Na}^{+}\right]_{\mathrm{i}}$ that results from the coupled uptake of $\mathrm{Na}^{+}$with glutamate into the astroglia. This uptake is mediated by a $\mathrm{Na}^{+} /$glutamate co-transporter that co-transports $2-3 \mathrm{Na}^{+}$ions with each glutamate molecule. In addition, much of the glutamate taken up by the astroglia is converted by glutamine synthetase to glutamine, a reaction consuming one ATP molecule for each molecule of glutamine formed. Inasmuch as it takes one molecule of ATP to pump out 


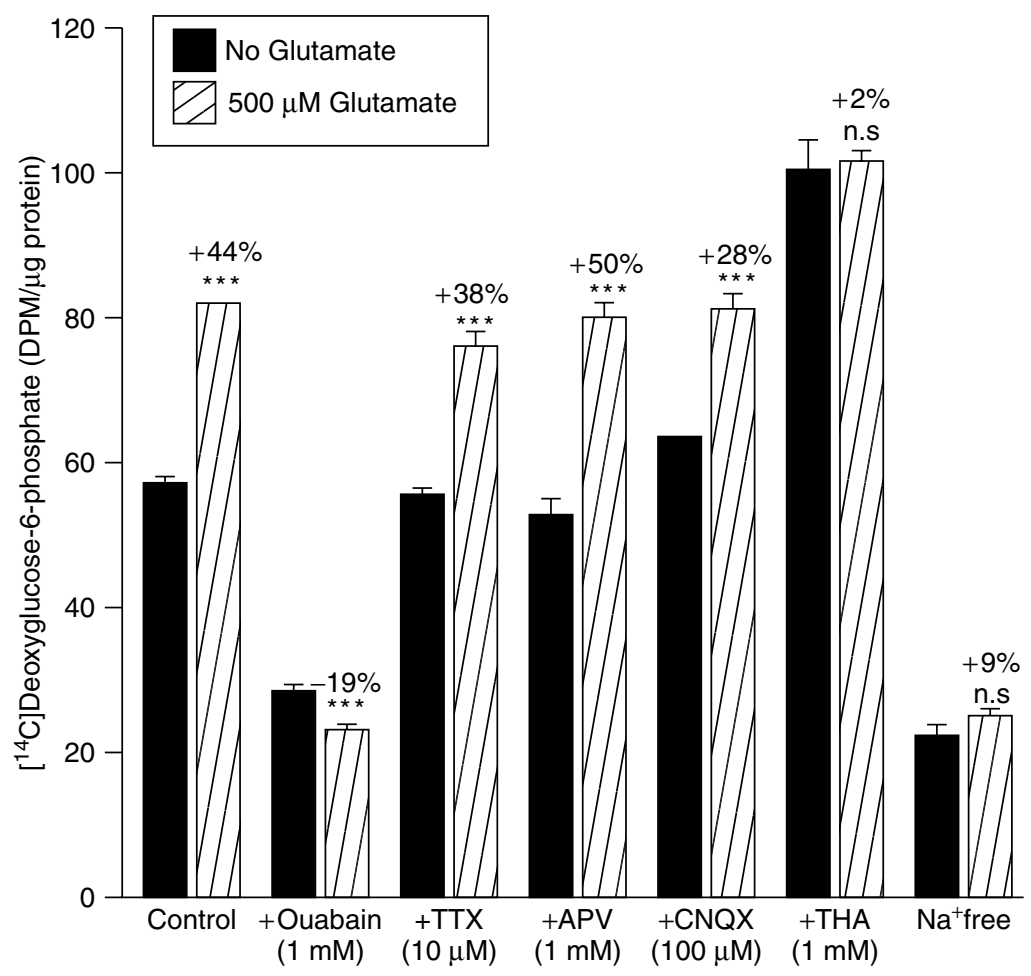

Figure 2.11. Effects of glutamate on $\left[{ }^{14} \mathrm{C}\right] \mathrm{DG}$ phosphorylation in astroglia and the effects of DL-2-amino-5-phosphonovaleric acid (APV), CNQX, ouabain, tetrodotoxin (TTX), DL-threo- $\beta$-hydroxyaspartic acid (THA), and $\mathrm{Na}^{+}$-free medium on the glutamate effects. Values are means \pm SEM obtained from quadruplicate wells, in three experiments, each with a different astroglial preparation. Numbers above bars indicate percent differences from each control. ${ }^{* * *} p<0.001$; n.s., not statistically significant, from each control group (grouped $\boldsymbol{t}$ test). From Takahashi et al. (1995). Similar results were reported by Pellerin and Magistretti (1994).

the 2-3 $\mathrm{Na}^{+}$ions co-transported inward with each molecule of glutamate taken up, and one molecule of ATP is consumed in converting the molecule to glutamine, it appears that the net gain of two molecules of ATP from the glycolysis of one molecule of glucose is consumed in the processing of one molecule of glutamate by astroglia.

\subsection{SUMMARY}

The main energy-consuming work of functionally activated neural tissues is related to the generation and propagation of action potentials and the disposition of the neurotransmitter molecules that are released at the synapses. Normally, the energy required by neural tissues is almost entirely derived from glucose metabolism which increases almost linearly with spike frequency when tissue is functionally activated. Spikes result from $\mathrm{Na}^{+}$influx and $\mathrm{K}^{+}$efflux in the neuronal elements where they are generated, and the greater the spike frequency the greater the ionic displacements. Increased extracellular $\mathrm{K}^{+}$and intracellular $\mathrm{Na}^{+}$concentrations stimulate $\mathrm{Na}^{+}, \mathrm{K}^{+}$-ATPase activity to restore the ionic gradients to their normal resting levels, and energy metabolism is then increased to resynthesize the ATP consumed in that process.

Functional activation of glucose utilization is essentially confined to neuropil which contains axonal, dendritic, and astrocytic processes. Obviously, some of the increased energy metabolism must occur in the 
axonal terminals and dendrites where the spikes are generated. Functional activation of energy metabolism is not seen in perikarya, presumably because they have few voltage-dependent $\mathrm{Na}^{+}$channels and, therefore, generate few if any action potentials.

Astrocytes contribute to the increased energy metabolism in neuropil during functional activation, but by other mechanisms. Astrocytic membranes can be depolarized by increased $\left[\mathrm{K}^{+}\right]_{\mathrm{i}}$, but they do not produce action potentials that would allow the $\mathrm{Na}^{+}$influx into the cells needed to stimulate $\mathrm{Na}^{+}, \mathrm{K}^{+}$-ATPase activity. Action potentials in axonal terminals, however, are associated with release of neurotransmitters. Glutamate is the most prevalent excitatory neurotransmitter in brain, but it is also a neurotoxin, and its extracellular concentration must be kept low by astrocytic reuptake via $\mathrm{Na}^{+}$-dependent glutamate transporters that transport 2-3 $\mathrm{Na}^{+}$ions with each glutamate molecule into the cell. The increased $\left[\mathrm{Na}^{+}\right]_{\mathrm{i}}$ then results in stimulation of $\mathrm{Na}^{+}, \mathrm{K}^{+}$-ATPase activity and energy metabolism. In addition, glutamate taken up by astroglia is converted there to glutamine, an energy-requiring reaction that also consumes ATP.

Astrocytic processes surround the capillaries that bring glucose to the brain, and some if not all the glucose must traverse them before reaching the neurons. Evidence has been accumulating that astrocytes first metabolize glucose to lactate which they then export to the neurons for oxidation to $\mathrm{CO}_{2}$ and $\mathrm{H}_{2} \mathrm{O}$ (Magistretti and Pellerin, 1996; Tsacopoulos and Magistretti, 1996). This would mean that glucose metabolism is compartmentalized between astroglia and neuronal elements, glycolysis in the astroglia and oxidation of the lactate/pyruvate products by the neurons. Glycolysis yields two molecules of ATP and two molecules of pyruvate/lactate per molecule of glucose glycolyzed. The two molecules of ATP produced in the astroglia are then consumed in the processing of each molecule of glutamate, suggesting that there may be a close quantitative relationship between glucose consumption and glutamate processing in the astroglia (Sibson et al., 1998). The oxidation of the two molecules of pyruvate/lactate produced from glycolysis of one molecule of glucose leads to the generation of 36 additional molecules of ATP which is consumed mainly for the restoration of the ionic gradients and the membrane potentials degraded by the action potentials.

\section{REFERENCES}

Badar-Goffer, R. S., Ben-Yoseph, O., Bachelard, H. S., and Morris, P. G. 1992. Neuronal-glial metabolism under depolarizing conditions. A ${ }^{13}$ C-n.m.r. study. Biochem. J. 282: 225-230.

Brookes, N., and Yarowsky, P. J. 1985. Determinants of deoxyglucose uptake in cultured astrocytes: the role of the sodium pump. J. Neurochem. 44: 473-479.

Clarke, D. D., and Sokoloff, L. 1999. Circulation and energy metabolism of the brain. In: Siegel, G., Agranoff, B., Albers, R. W., and Fisher, S. (Eds): Basic Neurochemistry: Molecular, Cellular, and Medical Aspects, 6th edn, Chapter 31. Lippincott-Raven, Philadelphia, PA, pp. 637-669.

Cummins, C. J., Glover, R. A., and Sellinger, O. Z. 1979a. Neuronal cues regulate uptake in cultured astrocytes. Brain Res. 170: 190-193.

Cummins, C. J., Glover, R. A., and Sellinger, O. Z. 1979b. Astroglial uptake is modulated by extracellular K ${ }^{+}$. J. Neurochem. 33: 779-785.

Erecinska, M., and Silver, I. A. 1994. Metabolism and role of glutamate in mammalian brain. Prog. Neurobiol. 43: $37-71$.

Flott, B., and Seifert, W. 1991. Characterization of glutamate uptake in astrocyte primary cultures from rat brain. Glia 4: $293-304$.

Freygang, W. H., Jr. 1958. An analysis of extracellular potentials from single neurons in the lateral geniculate nucleus of the cat. J. Gen. Physiol. 41: 543-564.

Freygang, W. H., Jr. and Frank, K. 1959. Extracellular potentials from single spinal motoneurones. J. Gen. Physiol. 42: 749-760.

Freygang, W. H., Jr. and Sokoloff, L. 1958. Quantitative measurements of regional circulation in the central nervous system by the use of a radioactive inert gas. Adv. Biol. Med. Phys. 6: 263-279.

Henn, F. A., Haljamäe, H., and Hamberger, A. 1972. Glial cell function: active control of extracellular $\mathrm{K}^{+}$concentration. Brain Res. 43: 437-443. 
Hertz, L. 1977. Drug-induced alterations of ion distribution at the cellular level of the central nervous system. Pharmacol. Rev. 29: 35-65.

Hertz, L., and Peng, L. 1992. Energy metabolism at the cellular level of the CNS. Can. J. Physiol. Pharmacol. 70 (Suppl.): S145-S157.

Kadekaro, M., Crane, A. M., and Sokoloff, L. 1985. Differential effects of electrical stimulation of sciatic nerve on metabolic activity in spinal cord and dorsal root ganglion in the rat. Proc. Natl. Acad. Sci., USA 82: 6010-6013.

Kennedy, C., Des Rosiers, M. H., Sakurada, O., Shinohara, M., Reivich, M., Jehle, J. W., and Sokoloff, L. 1976. Metabolic mapping of the primary visual system of the monkey by means of the autoradiographic $\left[{ }^{14} \mathrm{C}\right]$ deoxyglucose technique. Proc. Natl Acad. Sci. USA 73: 4230-4234.

Kety, S. S. 1950. Circulation and metabolism of the human brain in health and disease. Am. J. Med. 8: 205-217.

Kety, S. S., and Schmidt, C. F. 1948. The nitrous oxide method for the quantitative determination of cerebral blood flow in man: Theory, procedure, and normal values. J. Clin. Invest. 27: 476-483.

Krebs, H. A., Williamson, D. H., Bates, M. W., and Hawkins, R. A. 1971. The role of ketone bodies in caloric homeostasis. Adv. Enzyme Regul. 9: 387-409.

Landau, W. M., Freygang, W. H., Rowland, L. P., Sokoloff, L., and Kety, S. S. 1955. The local circulation of the living brain; values in the unanesthetized and anesthetized cat. Trans. Am. Neurol. Assoc. 80: 125-129.

Magistretti, P. J., and Pellerin, L. 1996. Cellular bases of brain energy metabolism and their relevance to functional brain imaging: Evidence for a prominent role of astrocytes. Cerebral Cortex 6: 50-61.

Mata, M., Fink, D. J., Gainer, H., Smith, C. B., Davidsen, L., Savaki, H., Schwartz, W. J., and Sokoloff, L. 1980. Activity-dependent energy metabolism in rat posterior pituitary primarily reflects sodium pump activity. J. Neurochem. 34: 213-215.

Medzihradsky, F., Nandhasri, P. S., Idoyaga-Vargas, V., and Sellinger, O. Z. 1971. A comparison of ATPase activity of the glial cell fraction and the neuronal perikaryal fraction isolated in bulk from rat cerebral cortex. J. Neurochem. 18: $1599-1603$.

Miyaoka, M., Shinohara, M., Batipps, M., Pettigrew, K. D., Kennedy, C., and Sokoloff, L. 1979. The relationship between the intensity of the stimulus and the metabolic response in the visual system of the rat. In: Cerebral Blood Flow and Metabolism. Gotoh, F., Nagai, H., and Tazaki, Y. (Eds). Hidejimi Seihanjo, Tokyo (Also, Acta Neurol. Scand., Suppl. 72, 60: 16-17).

Nordmann, J. J. 1977. Ultrastructural morphometry of the rat neurohypophysis. J. Anat. 123: 213-218.

Orkand, R. K., Nicholls, J. G., and Kuffler, S. W. 1966. Effect of nerve impulses on the membrane potential of glial cells in the central nervous system of amphibia. J. Neurophysiol. 29: 788-806.

Owen, O. E., Moran, A. P., Kemp, H. G., Sullivan, J. M., Herrera, M. G., and Cahill, G. F. 1967. Brain metabolism during fasting. J. Clin. Invest. 46: 1589-1595.

Pellerin, L., and Magistretti, P. J. 1994. Glutamate uptake into astrocytes stimulates aerobic glycolysis: A mechanism coupling neuronal activity to glucose utilization. Proc. Natl Acad. Sci. USA 91: 10625-10629.

Peng, L., Zhang, X., and Hertz, L. 1994. High extracellular potassium concentrations stimulate oxidative metabolism in a glutamatergic neuronal culture and glycolysis in cultured astrocytes but have no stimulatory effect in a GABAergic neuronal culture. Brain Res. 663: 168-172.

Phelps, M. E., Huang, S. C., Hoffman, E. J., Selin, C., Sokoloff, L., and Kuhl, D. E. 1979. Tomographic measurement of local cerebral glucose metabolic rate in humans with (F-18)2-fluoro-2-deoxy-d-glucose: validation of method. Ann. Neurol. 6: 371-388.

Reivich, M., Kuhl, D., Wolf, A., Greenberg, J., Phelps, M., Ido, T., Cassella, V., Fowler, J., Hoffman, E., Alavi, A., Som, P., and Sokoloff, L. 1979. The $\left[{ }^{18}\right.$ F]fluoro-deoxyglucose method for the measurement of local cerebral glucose utilization in man. Circulation Res. 44: 127-137.

Schwartz, W. J., Smith, C. B., Davidsen, L., Savaki, H., Sokoloff, L., Mata, M., Fink, D. J., and Gainer, H. 1979. Metabolic mapping of functional activity in the hypothalamo. Science 205: 723-725.

Shinohara, M., Dollinger, B., Brown, G., Rapoport, S., and Sokoloff, L. 1979. Cerebral glucose utilization: Local changes during and after recovery from spreading cortical depression. Science 203: 188-19.

Sibson, N. R., Dhankhar, A., Mason, G. F., Rothman, D. L., Behar, K. L., and Shulman, R. G. 1998. Proc. Natl Acad. Sci. USA 95: 316-321. 
Smith, C. B. 1983a. Localization of activity-associated changes in metabolism of the central nervous system with the deoxyglucose method: Prospects for cellular resolution. In: Barker, J. L., and McKelvy, J. F. (Eds): Current Methods in Cellular Neurobiology, Vol. I, Anatomical Techniques. Wiley, New York, pp. 269-317.

Smith, T. G, Jr. 1983b. Sites of action potential generation in cultured neurons. Brain Res. 288: 381-383.

Sokoloff, L. 1981. Localization of functional activity in the central nervous system by measurement of glucose utilization with radioactive deoxyglucose. J. Cereb. Blood Flow Metab. 1: 7-36.

Sokoloff. L., Reivich, M., Kennedy, C., Des Rosiers, M. H., Patlak, C. S., Pettigrew, K. D., Sakurada, O., and Shinohara, M. 1977. The $\left[{ }^{14} \mathrm{C}\right]$ deoxyglucose method for the measurement of local cerebral glucose utilization: Theory, procedure, and normal values in the conscious and anesthetized albino rat. J. Neurochem. 28: 897-916.

Takahashi, S., Driscoll, B. F., Law, M. J., and Sokoloff, L. 1995. Role of sodium and potassium in regulation of glucose metabolism in cultured astroglia. Proc. Natl Acad. Sci. USA 92: 4616-4620.

Tsacopoulos, M., and Magistretti, P. 1996. Metabolic coupling between glia and neurons. J. Neurosci. 16: 877-885.

Yarowsky, P., Boyne, A. F., Wierwille, R., and Brookes, N. 1986. Effect of monensin on deoxyglucose uptake in cultured astrocytes: energy metabolism is coupled to sodium entry. J. Neurosci. 6: 859-866.

Yarowsky, P., Kadekaro, M., and Sokoloff, L. 1983. Frequency-dependent activation of glucose utilization in the superior cervical ganglion by electrical stimulation of cervical sympathetic trunk. Proc. Natl Acad. Sci. USA 80: 4179-4183. 